\title{
Expression of Integrins and Basement Membrane Components by Wound Keratinocytes
}

\author{
Hannu Larjava, * Tuula Salo, * Kirsi Haapasalmi, * Randall H. Kramer, \\ Department of *Periodontology and "Medical Biochemistry, University of Turku, 20520 Turku, Finland; ${ }^{\ddagger}$ Department of Oral Surgery, \\ University of Oulu, Oulu Finland; and ${ }^{\S}$ Department of Stomatology, University of California, San Francisco, California 94143
}

\begin{abstract}
Extracellular matrix proteins and their cellular receptors, integrins, play a fundamental role in keratinocyte adhesion and migration. During wound healing, keratinocytes detach, migrate until the two epithelial sheets confront, and then regenerate the basement membrane. We examined the expression of different integrins and their putative ligands in keratinocytes during human mucosal wound healing. Migrating keratinocytes continuously expressed kalinin but not the other typical components of the basement membrane zone: type IV collagen, laminin, and type VII collagen. When the epithelial sheets confronted each other, these missing basement membrane components started to appear gradually through the entire wound area. The expression of integrin $\beta_{1}$ subunit was increased in keratinocytes during migration. The $\beta_{1}$-associated $\alpha_{2}$ and $\alpha_{3}$ subunits were expressed constantly by wound keratinocytes whereas the $\alpha_{5}$ subunit was present only in keratinocytes during reepithelialization. Furthermore, migrating cells started to express $\alpha_{\mathrm{v}}$-integrins which were not present in the nonaffected epithelium. All keratinocytes also expressed the $\alpha_{6} \beta_{4}$ integrin during migration. In the migrating cells, the distribution of integrins was altered. In normal mucosa, $\beta_{1}$-integrins were located mainly on the lateral plasma membrane and $\alpha_{6} \beta_{4}$ at the basal surface of basal keratinocytes in the nonaffected tissue. In wounds, integrins were found in filopodia of migrating keratinocytes, and also surrounding cells in several cell layers of the migrating sheet. The results indicate that migrating keratinocytes in deep human wounds enlarge their integrin repertoire. The changes in integrin expression take place concomitantly with changes in the basement membrane composition, suggesting a close interplay of these two groups of molecules during wound healing. (J. Clin. Invest. 1993. 92:1425-1435.) Key words: basement membrane • cell migration • integrins • keratinocytes • wound healing
\end{abstract}

\section{Introduction}

Keratinocytes maintain epidermal and mucosal surfaces and protect the organism from physical, chemical, or microbial attack (1). In wounds, the function of keratinocytes is to rapidly

Address reprint requests to Dr. Hannu Larjava, Department of Clinical Dental Sciences, Faculty of Dentistry, the University of British Columbia, 2199 Westbrook Mall, Vancouver, British Columbia, Canada V6T $1 \mathrm{Z3}$.

Received for publication 27 January 1993 and in revised form 20 April 1993.

J. Clin. Invest.

(c) The American Society for Clinical Investigation, Inc. $0021-9738 / 93 / 09 / 1425 / 11 \quad \$ 2.00$

Volume 92, September 1993, 1425-1435 cover the exposed underlying connective tissue (for review, see reference 2). During this process, keratinocytes detach themselves from the basement membrane, migrate laterally into the wound bed, and finally regenerate the basement membrane. Keratinocytes have been shown to synthesize most of the components, such as type IV collagen, laminin, and type VII collagen, which are present at the basement membrane zone (2). In a resting stage, keratinocytes adhere to each other and to the underlying basement membrane components. When keratinocytes migrate in the wound bed matrix, they are exposed to different adhesion proteins present in the connective tissue and in the blood clot (for reviews, see references 3 and 4 ). Cultured keratinocytes have been demonstrated to attach on a number of these adhesion proteins, namely various types of collagens, fibronectin, vitronectin, and thrombospondin (4). In all cases, most of these cell-matrix interactions of human keratinocytes are mediated by integrin-type cell surface receptors ( 5 ).

Integrins are heterodimeric cell surface receptors that bind extracellular matrix molecules including fibronectin, different types of collagens, and laminins (for reviews, see references 6-8). In general, cell adhesion on fibronectin is dependent on the Arg-Gly-Asp (RGD) sequence and mediated by several integrin receptors $\left(\alpha_{5} \beta_{1}, \alpha_{3} \beta_{1}, \alpha_{4} \beta_{1}, \alpha_{4} \beta_{7}, \alpha_{\mathrm{v}} \beta_{1}, \alpha_{\mathrm{v}} \beta_{6}, \alpha_{\mathrm{v}} \beta_{3}\right.$, $\alpha_{\mathrm{IIb}} \beta_{3}$ ). Different types of collagens are recognized mainly by one single receptor, the $\alpha_{2} \beta_{1}$-integrin. In some cell lines, the $\alpha_{1} \beta_{1}$ and $\alpha_{3} \beta_{1}$ also bind collagen. Both the $\alpha_{2} \beta_{1}$ and $\alpha_{3} \beta_{1}$ also serve as receptors for laminin together with other integrins $\left(\alpha_{1} \beta_{1}, \alpha_{6} \beta_{1}, \alpha_{6} \beta_{4}, \alpha_{7} \beta_{1}, \alpha_{\mathrm{v}} \beta_{3}\right)$. Based on immunolocalization studies, normal human keratinocytes in epidermis and in mucosa express the following integrins, the $\alpha_{2} \beta_{1}$, the $\alpha_{3} \beta_{1}$, and the $\alpha_{6} \beta_{4}(9-12)$. Keratinocytes are shown to be activated when kept in culture (see reference 4 ). As a consequence of this process, they start to express new integrins in addition to those found in vivo. The $\alpha_{5} \beta_{1}$ and the $\alpha_{\mathrm{v}} \beta_{5}$-integrins are found in cultured human keratinocytes but not in keratinocytes residing in the tissue (13-17). The ligand binding function of keratinocyte integrins has been evaluated using cultured cells. The $\alpha_{2} \beta_{1}$ and $\alpha_{5} \beta_{1}$ are specific to collagens and fibronectin, respectively $(13,14,18)$. The $\alpha_{3} \beta_{1}$-integrin has been reported to bind several ligands, namely fibronectin, collagen, laminin, and epiligrin $(5,14,15,19)$. The $\alpha_{6} \beta_{4}$-integrin localizes in hemidesmosome structures (20-23), probably binding to epiligrin (24) or kalinin (25) present in the anchoring filaments. Finally, the $\alpha_{v} \beta_{5}$-integrin mediates keratinocyte adhesion on vitronectin (14).

The purpose of this investigation was to find out whether the expression of integrins and their putative ligands change in human keratinocytes when they migrate in normal human incisional wounds. Expression of the $\beta_{1}$-integrins was found to be stimulated in migrating cells. Furthermore, keratinocytes were also found to express $\alpha_{5}$ and $\alpha_{\mathrm{v}}$-integrin subunits which were not found in the normal mucosa. The $\alpha_{\mathrm{v}}$-integrins were present only in keratinocytes that were not in contact with the base- 
ment membrane. Classical basement membrane components (laminin, type IV collagen), and type VII collagen were absent under migrating keratinocytes. Fibronectin and kalinin, were, however, present at the basal aspect of migrating keratinocytes in all stages of wound healing, serving as putative ligands for integrins.

\section{Methods}

Materials. This human experimental wound study was designed because most of the antibodies against integrin polypeptides recognize only human antigens. In addition, results from animal studies should be cautiously interpreted and are not always completely applicable to humans. The experimental protocol was approved by the Ethical Committee of the University of Turku in Finland. Five subjects volunteered for the study. Incisional V-shaped wounds ( $\sim 1.5 \mathrm{~cm}$ long, $2 \mathrm{~mm}$ wide and deep) were created in human palate (distal from the first premolar tooth, $\sim 4 \mathrm{~mm}$ from the gingival margin). Punch biopsies ( 4 or $6 \mathrm{~mm}$ ) were taken from the wounds on day $1(24 \mathrm{~h}), 3$, or 7 . Biopsies were rinsed in physiological saline, embedded in Tissuetek (Miles Inc., Elkhart, IN), and immediately frozen in liquid nitrogen. Specimens were stored at $-70^{\circ} \mathrm{C}$ until used. Frozen sections $(6 \mu \mathrm{m})$ were prepared and used for immunolocalization of integrins and their putative ligands. A set of sections was used for morphological analysis of wounds. Sections were stained by hematoxylin and eosin, and by toluidine blue using routine histological methods. Special staining techniques were used for localization of fibrin and the basement membranes. Using Mallory's phosphotungstic acid hematoxylin method (26) fibrin appeared as blue against brownish-pink stained collagen. Gomori's periodic acid methenamine silver method was used to histochemically stain the basement membrane. Using this technique basement membranes and elastic fibers appeared as black.

Immunofluorescence studies. Frozen sections $(6 \mu \mathrm{m})$ of experimental wound tissue were cut and fixed with $-20^{\circ} \mathrm{C}$ acetone for $5 \mathrm{~min}$ and stored at $-70^{\circ} \mathrm{C}$ until used. Immunolocalization of integrins was performed as described previously (27). Briefly, sections were incubated with primary antibodies diluted in PBS containing $1 \mathrm{mg} / \mathrm{ml}$ BSA for $60 \mathrm{~min}$, and rinsed with the same solution for $60 \mathrm{~min}$, after which sections were incubated with affinity-purified, rhodamine-conjugated secondary antibodies (dilution 1:50, Boehringer Mannheim Biochemicals, Indianapolis, IN) for $60 \mathrm{~min}$. After rinsing, specimens were mounted and examined using a Leitz Aristoplan epifluorescence microscope, and photographed using photoautomat (Wild MPS 46/52 Photoautomat; Wild Leitz Ltd., Heerbrugg, Switzerland). Antibodies against the following integrin subunits and ligands were used (sources

Table I. Antibodies Used to Recognize Different Integrins and Their Ligands in This Study

\begin{tabular}{llc}
\hline \multicolumn{1}{c}{ Integrin/ligand } & \multicolumn{1}{c}{ Antibody } & Reference \\
\hline$\beta_{1}$ & Serum, 3847 & 28 \\
$\beta_{3}$ & mAb 90BB10B7 & 29 \\
$\beta_{4}$ & mAb 345-11A & 30 \\
$\alpha_{1}$ & mAb TS2/7 & 31 \\
$\alpha_{2}$ & mAb 12F1 & 32 \\
$\alpha_{3}$ & mAb J143 & 33 \\
$\alpha_{5}$ & mAb BIIG2 & 34 \\
$\alpha_{6}$ & mAb GoH3 & 35 \\
$\alpha_{v}$ & mAb 1958 & Chemicon \\
Type IV collagen & mAb & ICN Biomedicals \\
Type VII collagen & mAb 1345 & Chemicon \\
Laminin & Serum & 36 \\
Kalinin & mAbGB3 & 37 \\
\hline
\end{tabular}

for antibodies are given in Table I; see references 28-37): $\alpha_{1}, \alpha_{2}, \alpha_{3}, \alpha_{5}$, $\alpha_{6}, \alpha_{v}, \beta_{1}, \beta_{3}, \beta_{4}$, fibronectin, type IV collagen, laminin, type VII collagen, and kalinin. Control stainings were performed using nonimmune rabbit and mouse sera in different dilutions.

Relative amounts of $\beta_{1}$-integrins in the basal cell layer of nonaffected oral mucosa were compared to that in the leading front of the migrating epithelial sheet of 3-d-old wounds as follows: the image of fluorescence intensity was reproduced from high-contrast black and white negatives on a computer screen, and the background was substracted automatically using nonstained areas of the sections after which the staining intensity was recorded by means of a densitometer (computing densitomer, model 300A; Molecular Dynamics Sunnyvale, $C A$ ). The area measured was adjusted to correspond to the thickness of the basal cell layer on the computer screen.

\section{Results}

Morphology of the healing tissue. All experimental wounds healed normally without complications. On day 1 , the wound area was clearly distinguishable and filled with the fibrin clot (Fig. $1 A$ ). The first signs of epithelial migration were visible. Keratinocytes at the wound margin extended the filopodia (seen only with high magnification; not shown) into the clot area, and a few cells had already moved laterally into the wound site. $3 \mathrm{~d}$ after wounding, fibrin was still clearly present in the wound. Epithelial sheets had moved markedly forward into the wound area (Fig. $1 B$ ). The leading edge of the epithelial sheet was $\sim 300 \mu \mathrm{m}$ from the original wound margin. Epithelial keratinocytes appeared to migrate inside the fibrin-rich matrix. Leading cells were not in contact with the connective tissue collagen matrix. Chemical staining of the basement membranes revealed that migrating keratinocytes did not deposit and organize basement membrane (see below).

On day 7 after wounding, the epithelial sheets migrating from opposite directions confronted (Fig. $1 C$ ). The wound gap under the surface epithelium was still clearly visible, especially when fibrin staining was used. The first novel collagen fibers were seen under the united epithelium and at the wound base. Hematoxylin and eosin staining revealed that morphologically the wound gap was filled with granulation tissue. However, there still was fibrin present between the emerging fibers and cells of the connective tissue. Histochemical staining revealed that properly organized basement membrane was still absent under the epithelium covering the granulation tissue (Fig. 2).

Localization of basement membrane-associated components. In the nonwounded area of human oral mucosa, the classical components of the basement membrane (laminin and type IV collagen) were localized in the basement membranes of the surface epithelium and blood vessels. Staining of the type VII collagen (a component of anchoring fibrils) or kalinin (a component of anchoring filaments) decorated the basement membrane zone under the surface epithelium but both were absent around blood vessels. Fibronectin was present through the entire connective tissue. In 1-d-old wound specimens, type IV collagen and laminin were localized in similar fashion as in the nonaffected oral mucosa (Fig. 3, $A$ and $D$ ). $3 \mathrm{~d}$ after wounding, laminin and types IV and VII collagen were, however, absent under migrating human keratinocytes (Fig. 3, $B$ and $E$ and Fig. $4 B$ ). Fibronectin was localized in the connective tissue and the clot area in both 1- and 3-d-old samples (Fig. $3, G$ and $H$ ). A concentration of fibronectin in a bandlike deposition under the migrating epithelial cell sheet was seen in 

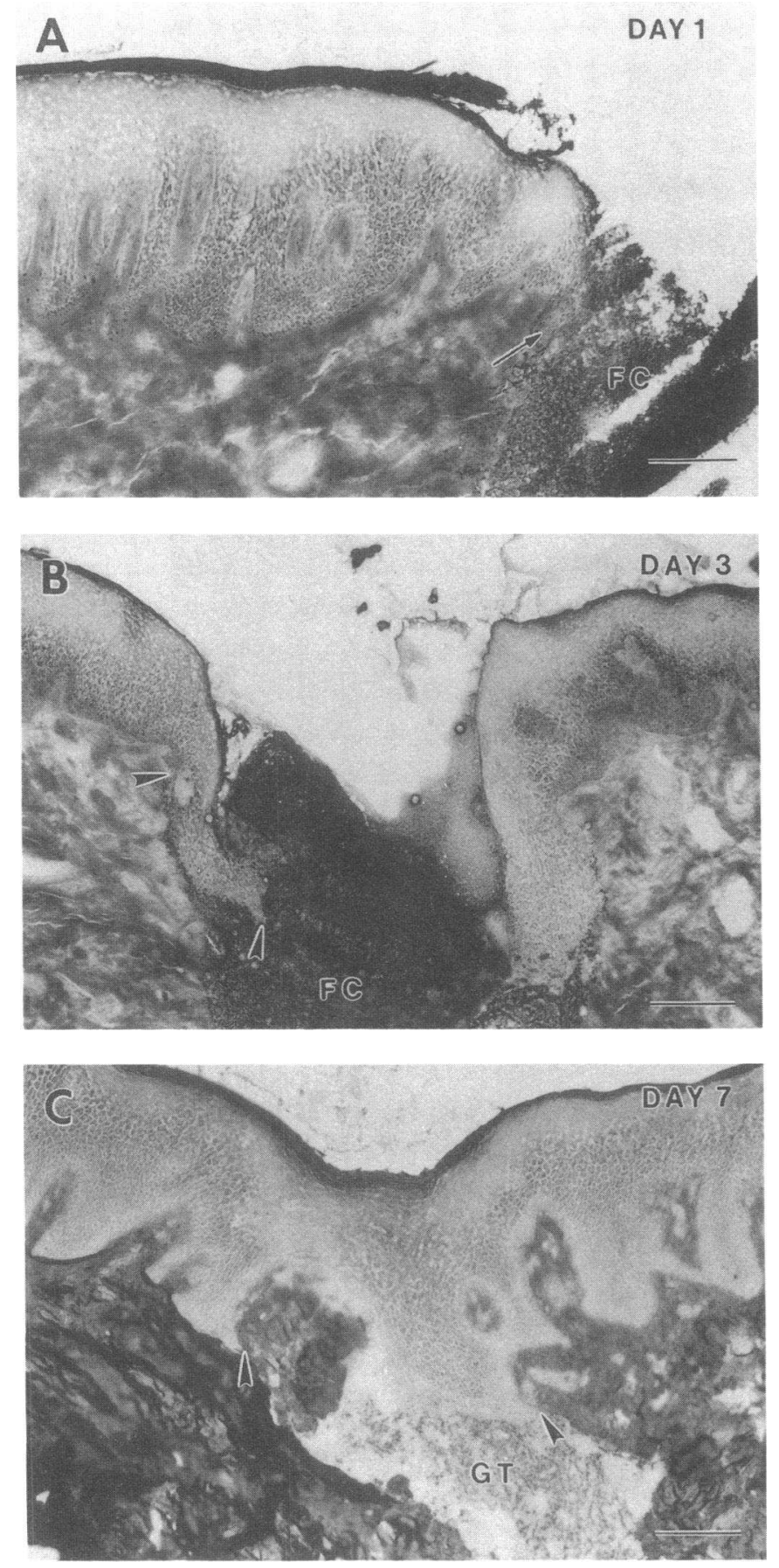

Figure 1. Fibrin staining (Mallory's phosphotungstic acid hematoxylin) of mucosal wounds after $(A) 1,(B) 3$, and $(C) 7 \mathrm{~d}$ of healing. $(A)$ The first keratinocytes appear to have started migration (arrow). $(B)$ The migrating leading front of the epithelial sheet is marked with arrowheads. $(C)$ Two epithelial sheets have confronted each other; note the area where basement membrane is still missing (see later figures) is marked with arrowheads. Abbreviations: $F C$, fibrin clot; $G T$, granulation tissue. Bar, $50 \mu \mathrm{m}$.

3-d-old wounds (Fig. $3 H$ ). $7 \mathrm{~d}$ after wounding, the two epithelial sheets joined and fully covered the wound area. The first signs of regeneration of type IV collagen and laminin (Fig. 3, C and $F$ ) at basement membrane zone were seen at the basal aspect of keratinocytes covering the wound. Staining of lami- nin and type IV collagen was, however, still weak and discontinuous. Newly formed blood vessels in the granulation tissue were strongly positive for type IV collagen and laminin indicating a continuous deposition of these components during neovascularization (Fig. 3, $C$ and $F$ ).

Localization of the components present in the epithelial anchoring apparatus revealed an interesting distribution (Fig. 4). Type VII collagen, which is found in the anchoring fibers, was absent below the migrating epithelial sheets of 3-d-old wounds (Fig. $4 \mathrm{~B}$ ). It started to reappear at the basement membrane zone on day 7 after wounding (Fig. $4 C$ ). As with type IV collagen and laminin (Fig. 3), type VII collagen was only weakly and discontinuously present under the recently united epithelial sheets. Interestingly, kalinin, the newly discovered component of the anchoring filaments, was deposited by the migrating keratinocytes during all phases of wound healing (Fig. $4, D-F$ ). Already on day 1 after wounding, kalinin was seen under the first cells that had started lateral migration into the wound area.

Expression of integrins in wound keratinocytes. Integrins of the $\beta_{1}$ family were localized mainly in the basal layer of the nonaffected oral mucosa as described earlier (38). Stimulation of $\beta_{1}$-integrin expression was seen at the wound margin already in 1-d-old wounds (Fig. $5 A$ ). $3 \mathrm{~d}$ after wounding, the expression of the $\beta_{1}$-integrins was still strongly stimulated in keratinocytes of the leading front (Fig. $5 \mathrm{~B}$ ). Based on the intensity of the immunofluorescence, the relative amount of $\beta_{1}$-integrins was increased by $\sim 1.5$-fold in the migrating keratinocytes as compared with the cells in the nonaffected area in the same specimen (measured by densitometry, not shown). Also the distribution of $\beta_{1}$-integrins changed in the migrating epithelial sheets. In nonwounded area, $\beta_{1}$-integrins were mainly localized around the basal cells, most of the staining being intercellular. In wounds, keratinocytes extended filopodia-like extensions into the wound bed that were strongly positive for $\beta_{1}$-integrins. Several $\beta_{1}$-associated $\alpha$ subunits were expressed by the migrating keratinocytes. Some of these $\alpha$ subunits were also present in the epithelium of normal mucosa $\left(\alpha_{2}\right.$ and $\left.\alpha_{3}\right)$ while others $\left(\alpha_{5}\right)$ were found to be expressed only by the migrating epithelial sheet (see Figs. 5 and 6). Localization of the $\alpha_{2}$ and $\alpha_{3}$ subunits in wound epithelium was similar and they showed codistribution with the $\beta_{1}$ subunit (Fig. 5). In the nonaffected epithelium, only the basal cells were integrin positive while several cell layers appeared integrin positive after wounding. The $\alpha_{5} \beta_{1}$ fibronectin receptor was only expressed in keratinocytes of the migrating sheets (Fig. 6, $C$ and $D$ ). The nonwounded area was practically devoid of signal for the $\alpha_{5}$. The $\alpha_{5} \beta_{1}$ receptor was localized specifically in cell extensions of the most basal cells in the migrating sheet (Fig. $6 \mathrm{D}$ ). The expression of the $\alpha 5$ was localized only in keratinocytes that were not depositing basement membrane components (see Fig. 3). 7 days after wounding, the distribution of $\beta_{1}$-integrins started to normalize (Fig. 5 ). There was, however, a strong expression of $\beta_{1}$-integrins in the granulation tissue. Immunostaining of the $\alpha_{1}$ or $\alpha_{4}$ (not shown) integrin subunits of wound specimens gave no specific signal, and was comparable to the stainings performed using nonimmune sera (Fig. $6 \mathrm{~B}$ ).

In the nonwounded area, the $\alpha_{6}$ - and $\beta_{4}$-integrin subunits colocalized at the basal surface of basal keratinocytes (Fig. 7). In 1-d-old wounds, stainings of both $\alpha_{6}$ and $\beta_{4}$ surrounded keratinocytes at the wound margin. At the leading edge of 3-dold wounds, the $\alpha_{6}$ was distributed around the migrating cells, 

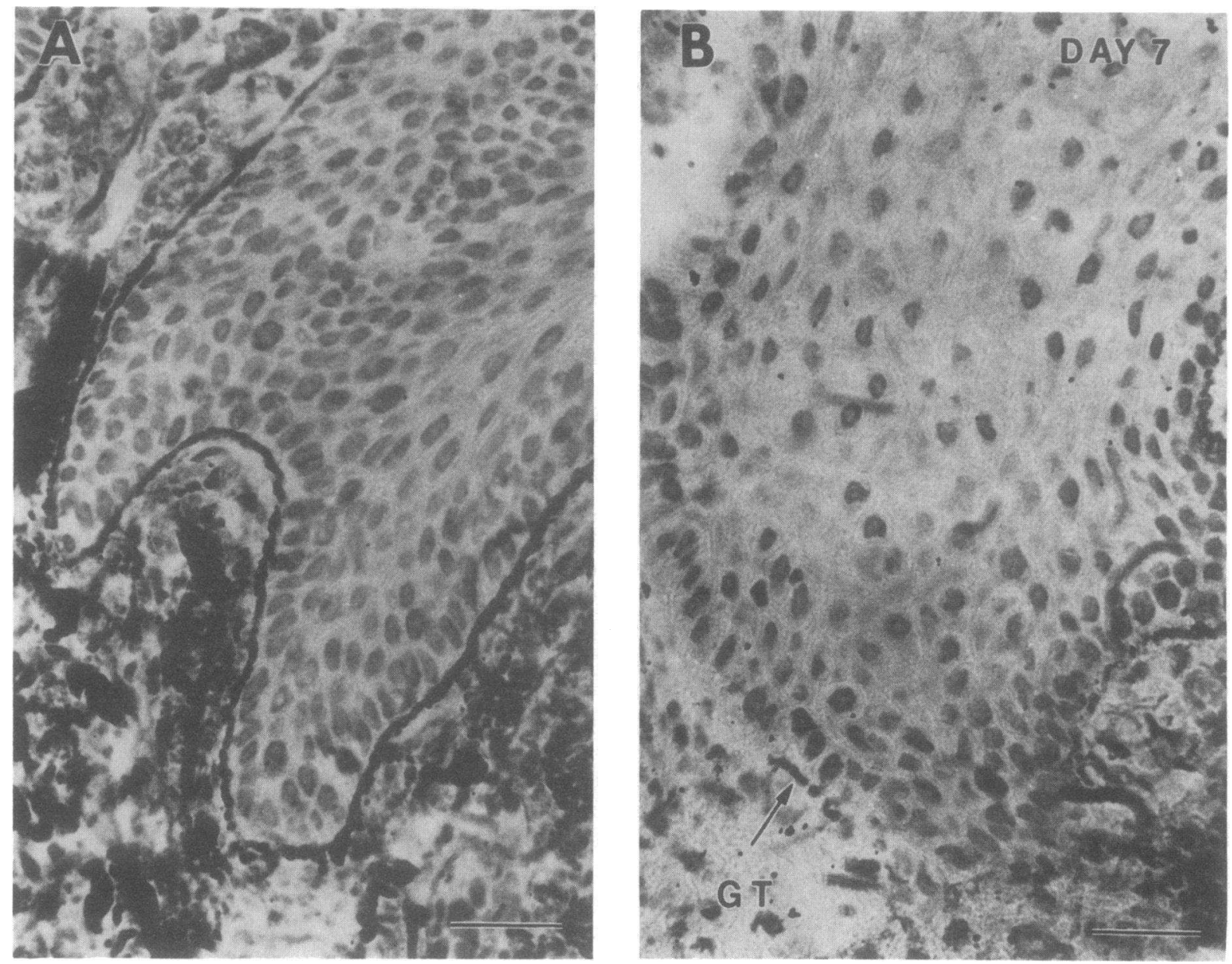

Figure 2. Gomori's periodic acid methenamine silver staining of basement membranes in 7-d-old wounds. $(A)$ Staining of nonaffected mucosa; $(B)$ staining of area of united wound epithelium. Arrows indicate the sporadic appearance of basement membrane at the wound site. Bar, 20 $\mu \mathrm{m}$.

often in several cell layers in cell-cell contacts, and also in the filopodia of the most basal cells in the migrating sheet. Immunolocalization of $\alpha_{6}$ and $\beta_{4}$ in 7-d-old wounds resembled that in the nonaffected mucosa (Fig. 7, $C$ and $F$ ). Neither subunit was found to be expressed in the granulation tissue.

Keratinocytes of the normal human mucosa did not express the $\alpha_{\mathrm{v}}$-integrins. Cells in the migrating epithelial sheet were, however, positive for the $\alpha_{\mathrm{v}}$-integrins (Fig. 6, $E$ and $F$ ). The $\alpha_{v}$ subunit was expressed in the same area as the $\alpha_{5} \beta_{1}$ fibronectin receptor. Localization of the $\alpha_{\mathrm{v}}$-integrin was strongest at the most basal aspect of the migrating keratinocytes. We then localized the $\beta_{3}$-integrin in the wounds to analyze whether this integrin was associated with the $\alpha \mathrm{v}$ subunit. The $\beta_{3}$-integrin subunit did not colocalize with the $\alpha_{\mathrm{v}}$-integrin (Fig. $6 \mathrm{~A}$ ). It was found, however, at the wound margin underneath the epithelium. The expression of the $\alpha \mathrm{v}$ integrin was still localized in basal keratinocytes covering the wound area of 7-d-old samples (Fig. 6, $G$ and $H$ ). Again, the $\alpha \mathrm{v}$ integrin was found in keratinocytes that were not contacting the fully reconstituted basement membrane.

\section{Discussion}

During wound healing, the migration of the surface epithelium to cover the exposed connective tissue is critical for the survival of the organism. This migration starts within hours after injury and continues until the epithelial surface is intact $(2,39)$. In this paper, we demonstrate that, during the migration process, whereas keratinocytes do not deposit type IV collagen, laminin, or type VII collagen, they increase the expression of specific integrin subunits to migrate over matrix rich in fibronectin and kalinin.

We used human oral mucosa as a model to study human wound healing because of the following advantages. In human palatal mucosa, hairs and salivary glands are absent. Therefore, the epithelium arises from the wound periphery rather than from hair or glandular epithelia as is often the case in epidermal wound healing (39). This makes the interpretation of the results easier. Oral wounds also heal rapidly and often without significant scar formation.

Migrating keratinocytes of human oral mucosa did not deposit type IV collagen or laminin when they moved in wounds. This pattern of the regeneration of the basement membrane zone components in human mucosal wounds agrees with earlier studies with epidermal wounds $(40,41)$. Type VII collagen is a major structure of anchoring fibers (42-44). Also, type VII collagen was absent under the migrating epithelial cells. All these three components of the basement membrane zone are believed to be synthesized mainly by keratinocytes (45). When the two epithelial sheets confronted each other in 7-d-old 

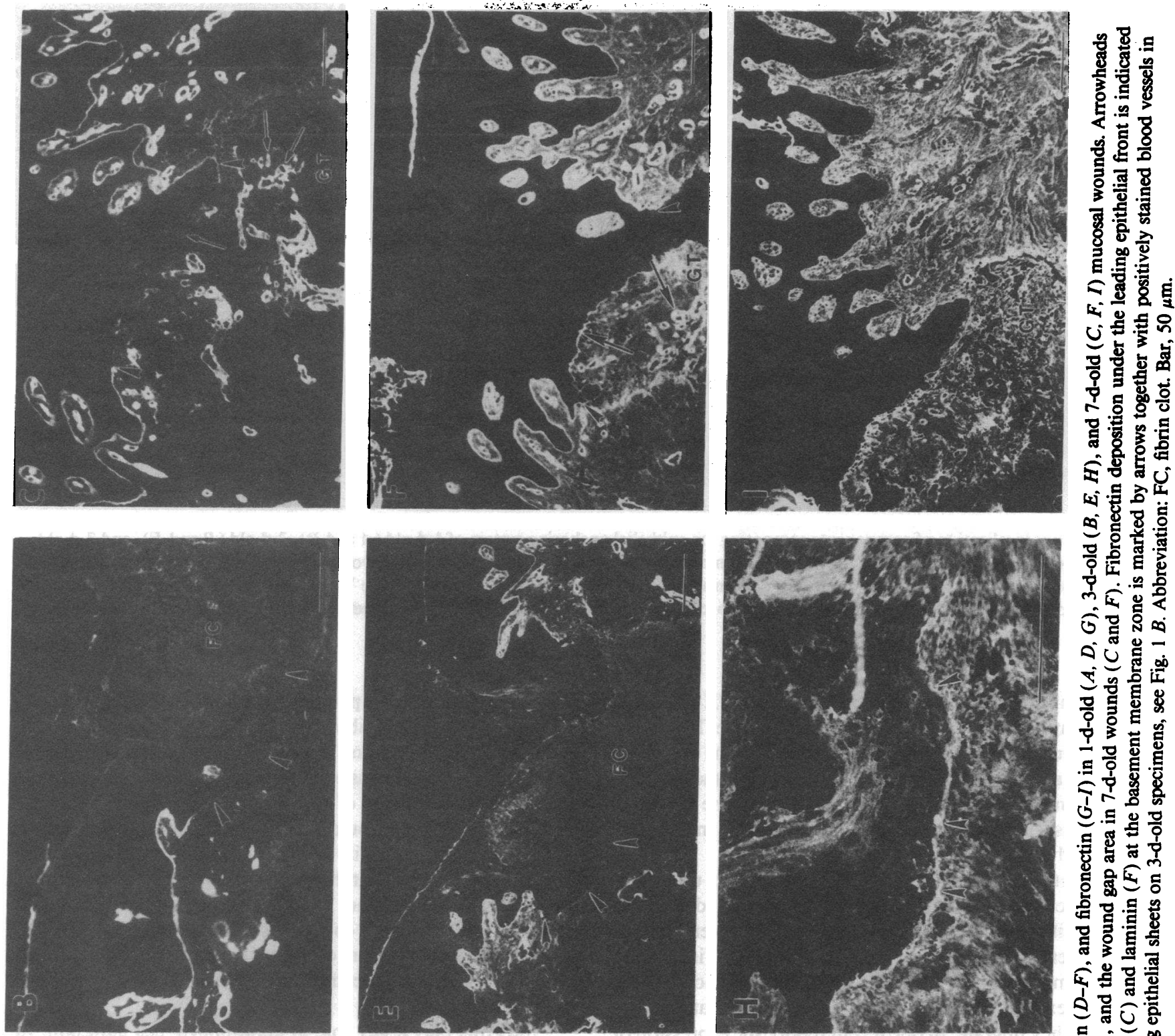

ज记 象 훙

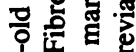
它曲 近定 (1) 유 Q U

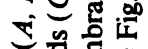
응 뺑 iे 흥 흥 궁 ن. 용요

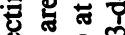
号雪 它 ช 总聶 的焉要 ํํำ .5 可实
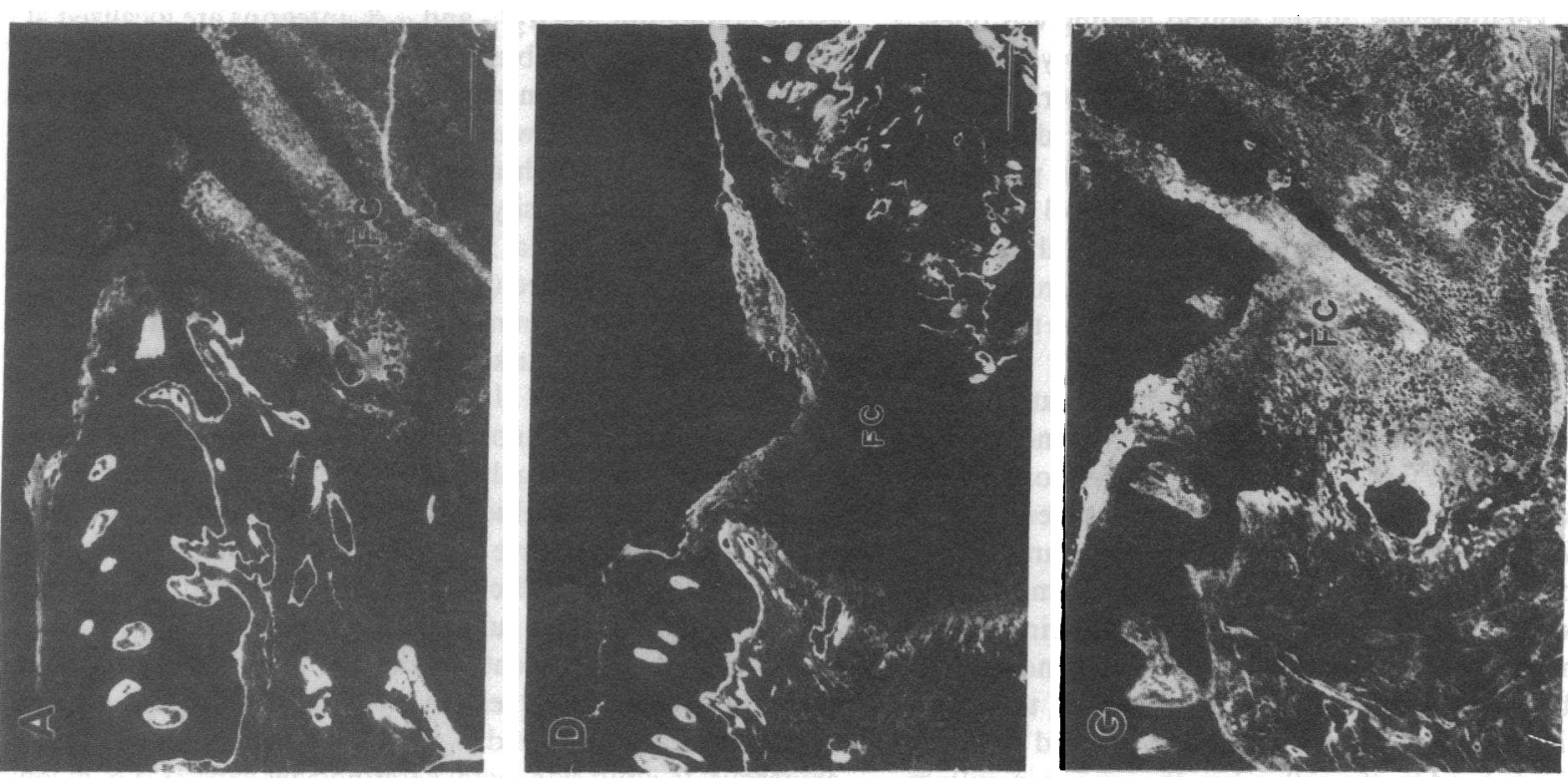

馬 可 Oิ口 능 उ 赵事 흥 믕 흉 8 웅 舟娄 \% $\Xi$ 过

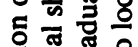

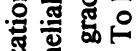
产言要 8 . 을 蛋 E完 $m$ 递 농

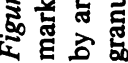



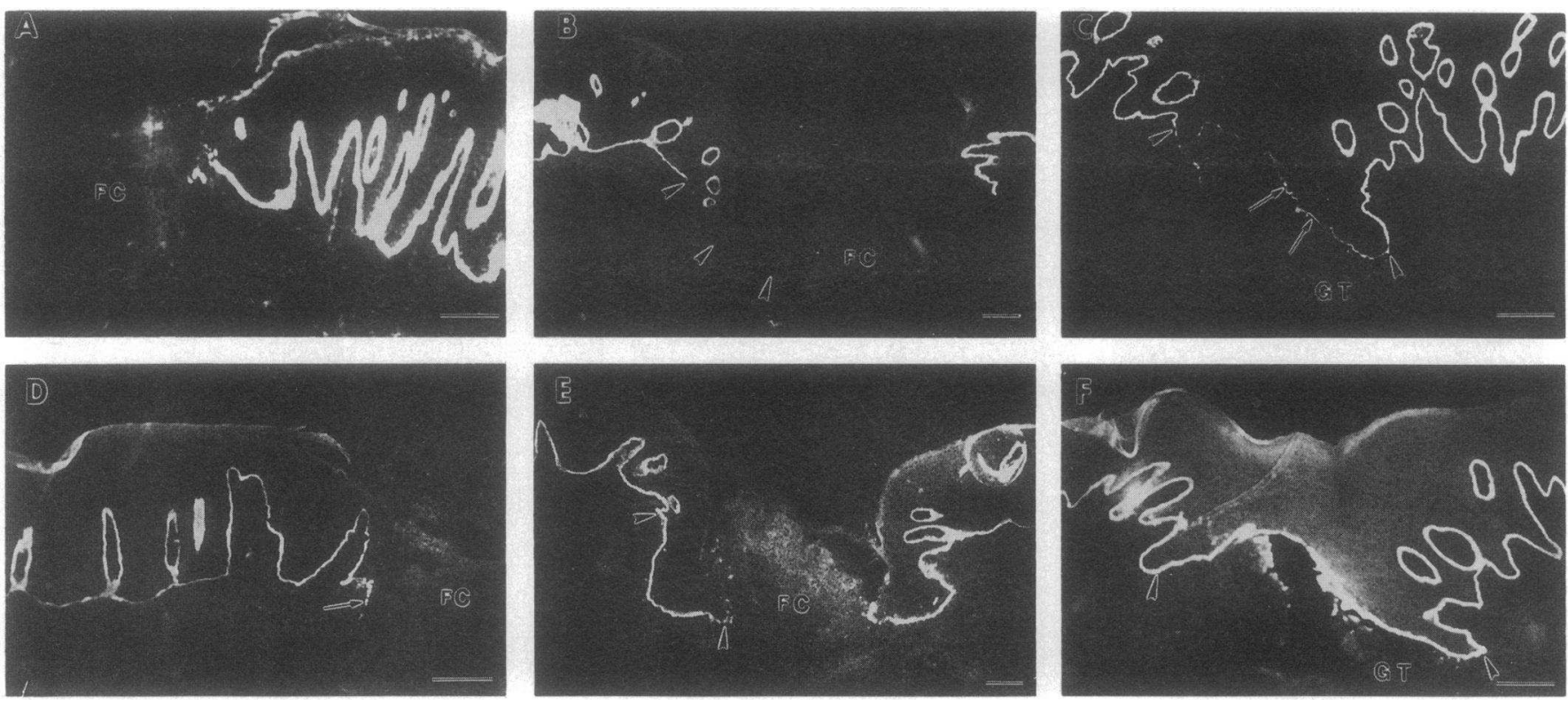

Figure 4. Immunolocalization of components composing the epithelial anchoring system of 1-d-old $(A$ and $D), 3-d-o l d ~(B$ and $E)$, and 7-d-old $(C$ and $F$ ) wounds. $(A-C)$ Type VII collagen; $(D-F)$ kalinin. Arrowheads in $B, C, E$, and $F$ mark the wound epithelium (see Fig. 1$)$. Note that the first migrating keratinocytes appear positive in kalinin staining $(D$, arrow $)$. Reconstruction of type VII collagen at the basement membrane zone in 7-d-old wounds is marked with an arrow $(C)$. To localize the leading edge of the epithelial sheets of 3-d-old samples see Fig. $1 B$. Bar, $50 \mu \mathrm{m}$.

wounds laminin, type IV collagen, and type VII collagen started to reappear at the basement membrane zone. The localization pattern was discontinuous indicating that the epithelial sheets of small wounds first move, confront, and then reconstruct the entire basement membrane at the same time. In other models, the reorganization of the basement membrane starts behind the leading edge $(40,41)$.

Fibronectin was present in the fibrin-rich matrix under the migrating keratinocytes during all phases of wound healing. The role of fibronectin during wound healing has been emphasized in several reviews $(3,4,46,47)$. Fibronectin is initially derived from plasma into the clot but later keratinocytes are believed to express their own cellular fibronectin that they deposit when they migrate. In one recent report, the expression of fibronectin by keratinocytes during wound healing was questioned (48). In wound granulation tissue, also embryonic type of fibronectin is synthesized (48). There is, however, no clear evidence that keratinocyte adherence on these differently spliced fibronectins would be different. Fibronectin promotes keratinocyte adhesion and migration in vitro (49-51). Keratinocytes also leave fibronectin trails behind when they move in culture. It is evident and well recognized that fibronectin is one of the key molecules promoting cell migration in the provisional wound matrix (4).

Laminin was not expressed by the migrating keratinocytes. This is not surprising since laminin promotes keratinocyte cell adhesion poorly and, in fact, it inhibits their migration in vitro $(18,52)$. Several laminin homologues have been recently identified. In addition to the classical laminin, merosin, and s-laminin (53), also kalinin (25), epiligrin (24), and K-laminin (54) are found in different basement membranes. Epiligrin is a new member of the group of proteins present in the basement membranes. It is believed to be similar, if not identical, to kalinin (55). Epiligrin promotes keratinocyte adhesion and it is, like fibronectin, left behind by the cells when they move in culture
(24). Epiligrin is also a putative ligand for both $\alpha_{6} \beta_{4}$ and $\alpha_{3} \beta_{1}$ integrins (24). Our antibody specifically stains the epidermal basement membrane and it is specific for kalinin $(37,55)$. Interestingly, kalinin was expressed by the migrating keratinocytes during all phases of wound healing. It is possible that laminin and kalinin could function differently in regulating keratinocyte migration in wounds. Laminin could be synthesized to stop the cell migration and to frame the organization of the basement membrane. The function of kalinin in wounds remains to be shown. It could possess a dual function, serving as a structural component of the anchoring filaments in nonaffected tissue and as an extracellular ligand promoting cell migration in wounds.

Integrins play a key role in keratinocyte cell adhesion. In resting epithelium, the $\alpha_{2} \beta_{1}$ - and $\alpha_{3} \beta_{1}$-integrins are localized at the lateral plasma membranes and they are proposed to function as cell-cell adhesion molecules $(10-12,27,38)$. The expression of $\beta_{1}$-integrins was clearly stimulated in keratinocytes during mucosal wound healing. Previously, some evidence for increased staining intensity of $\beta_{1}$-integrins in keratinocytes migrating in deep epidermal wounds and out of skin explants in culture has been reported (56-58). In more superficial, blister wounds, where basement membrane partially remains, we and others have not seen strikingly altered expression of $\beta_{1}$-integrins ( 59; J. Peltonen et al., unpublished data). It is probable, therefore that the keratinocyte migration and integrin expression are differentially regulated in cases where basement membrane is still present or absent. Indeed, our results strongly suggest that there is an inverse relationship between the expression of some integrins and the presence of basement membrane. The $\alpha_{v}-$ and $\alpha_{5}$-integrin subunits were expressed only, if keratinocytes were not in contact with the basement membrane. Both integrins are rarely seen in the resting epithelium. During development, $\alpha_{v}(10)$ and $\alpha_{5} \beta_{1}(10,12)$ are expressed in the epidermis. In adult skin, basal keratinocytes express $\alpha_{5} \beta_{1}$ at low 

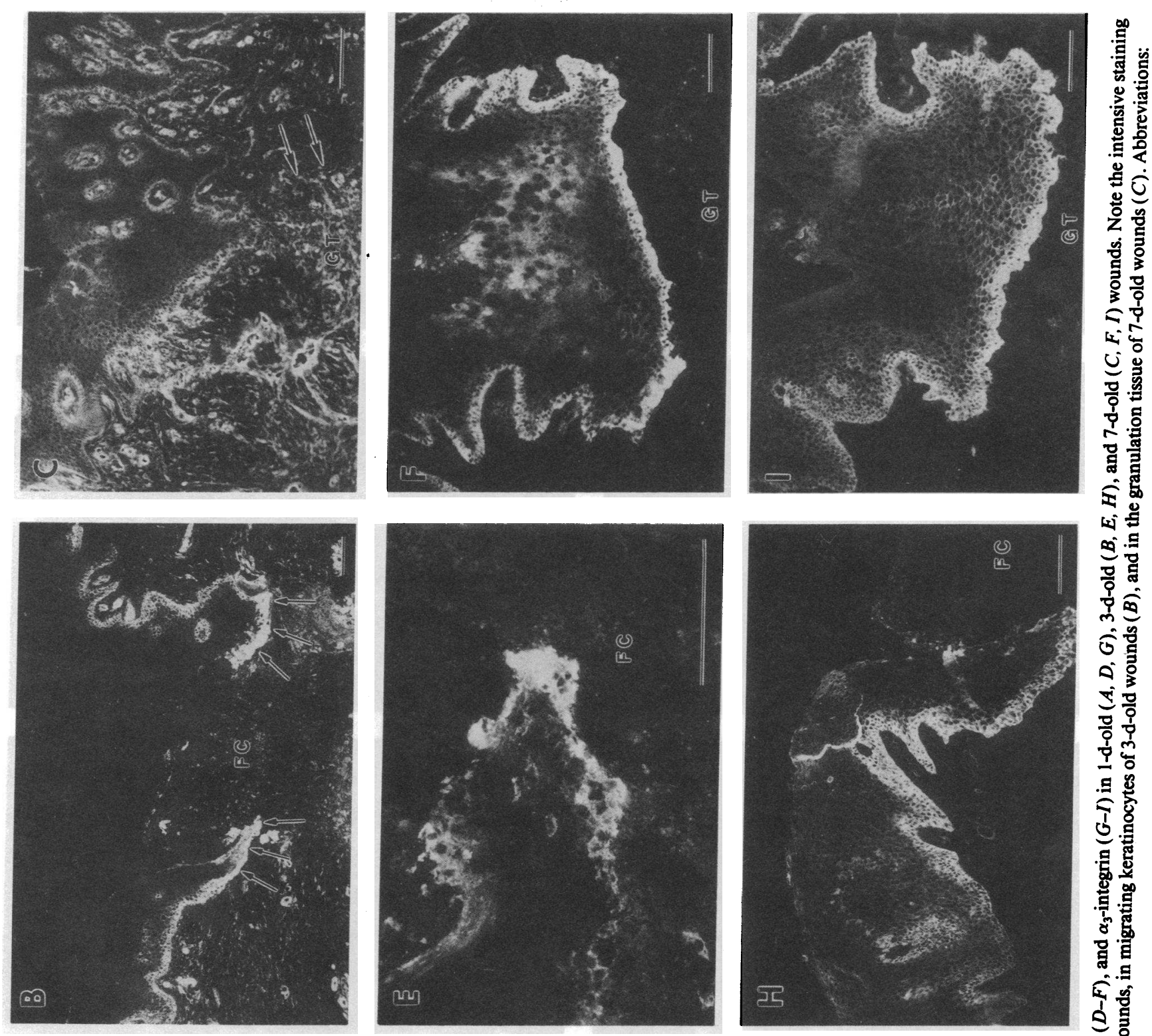

जी

$\infty .5$

흥

ㅇํำ

की

(6)

si

훙

흥ํํㄹ

도

吕密

ड़

员意

.

需 恖

흘

\&.1

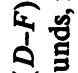
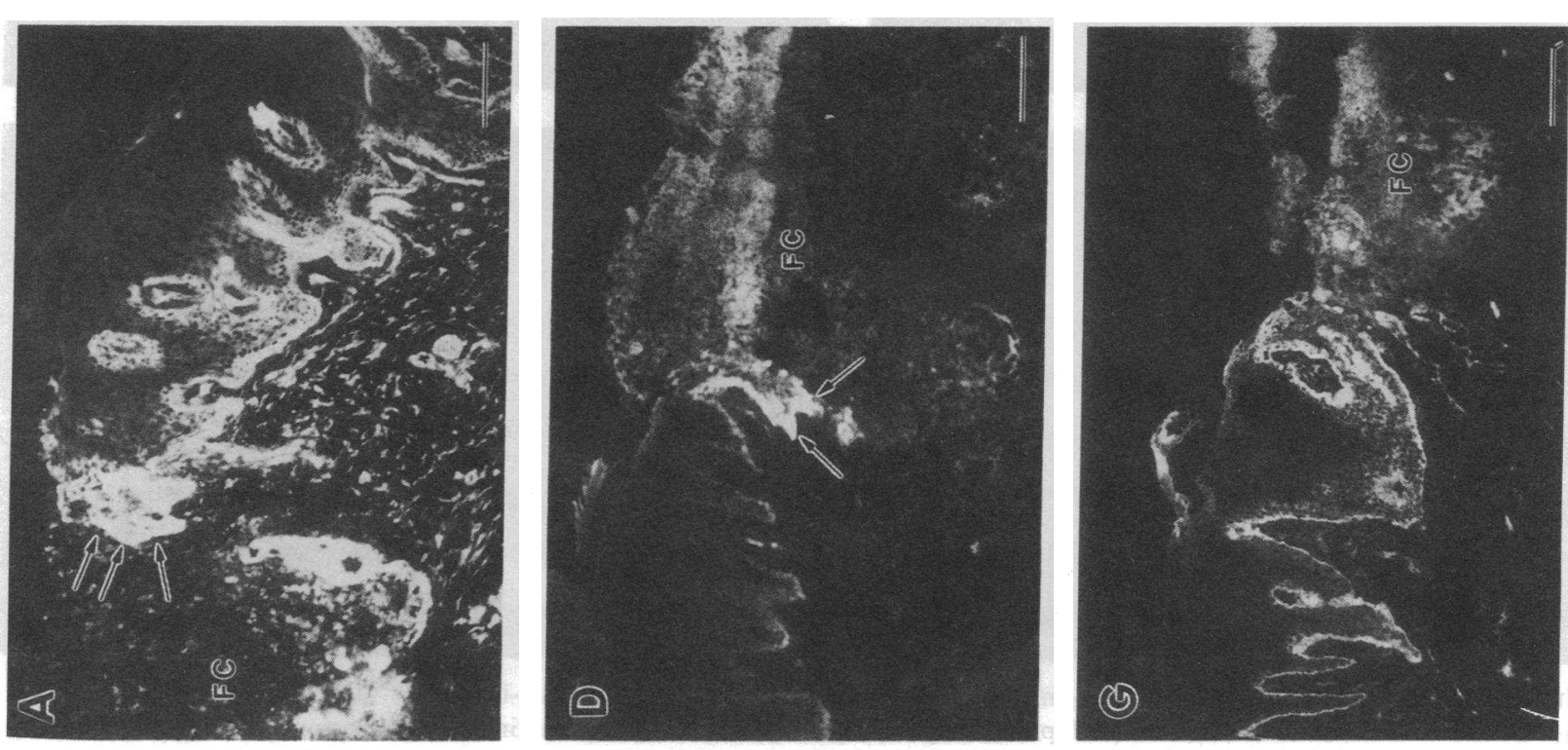

:

影

.

की

บิธูป

종

들 궁

可

형

-

영

ธํํ요

证

긍

要过

思

틍

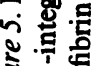

so 

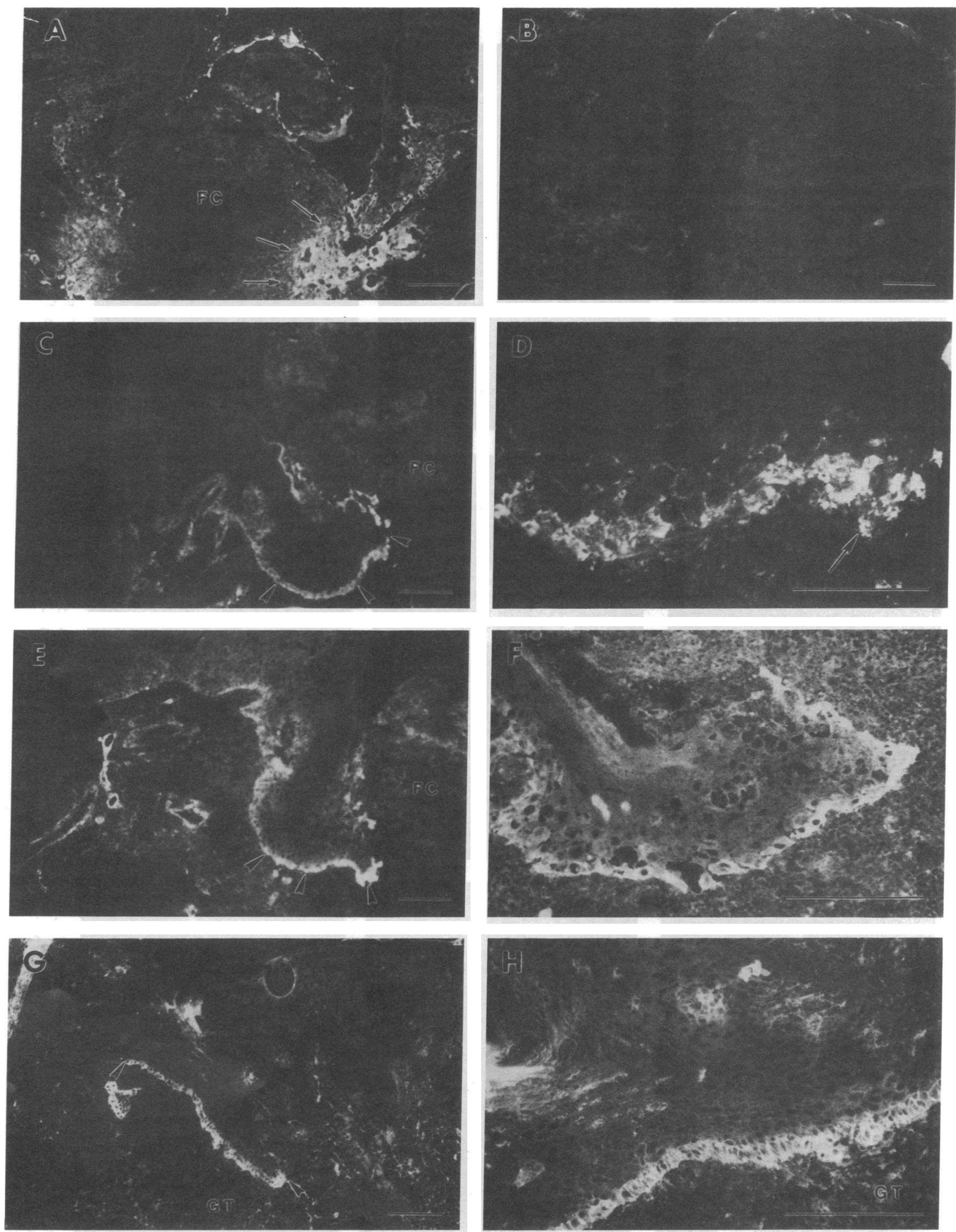

Figure 6. Immunolocalization of $\beta_{3}$-integrins $(A) ; \alpha_{4}$-integrin $\left(\alpha_{1}\right.$ staining corresponds to $\left.\alpha_{4}\right)(B) ; \alpha_{5}$-integrin $(C-D)$; and $\alpha_{v}$-integrin $(E-H)$ in 3-d-old $(A-F)$ and 7-d-old wounds $(G-H) . D$ and $F$ present higher magnifications of leading keratinocytes in specimens corresponding to stainings in $C$ and $E\left(\alpha_{s}\right.$ and $\alpha_{v}$, respectively). $H$ presents a higher magnification of $G$ demonstrating a closer view of $\alpha_{v}$ expressing basal keratinocytes above the granulation tissue. Abbreviations: FC, fibrin clot; GT, granulation tissue. Bar, $50 \mu \mathrm{m}$ except $20 \mu \mathrm{m}$ for $D$. 

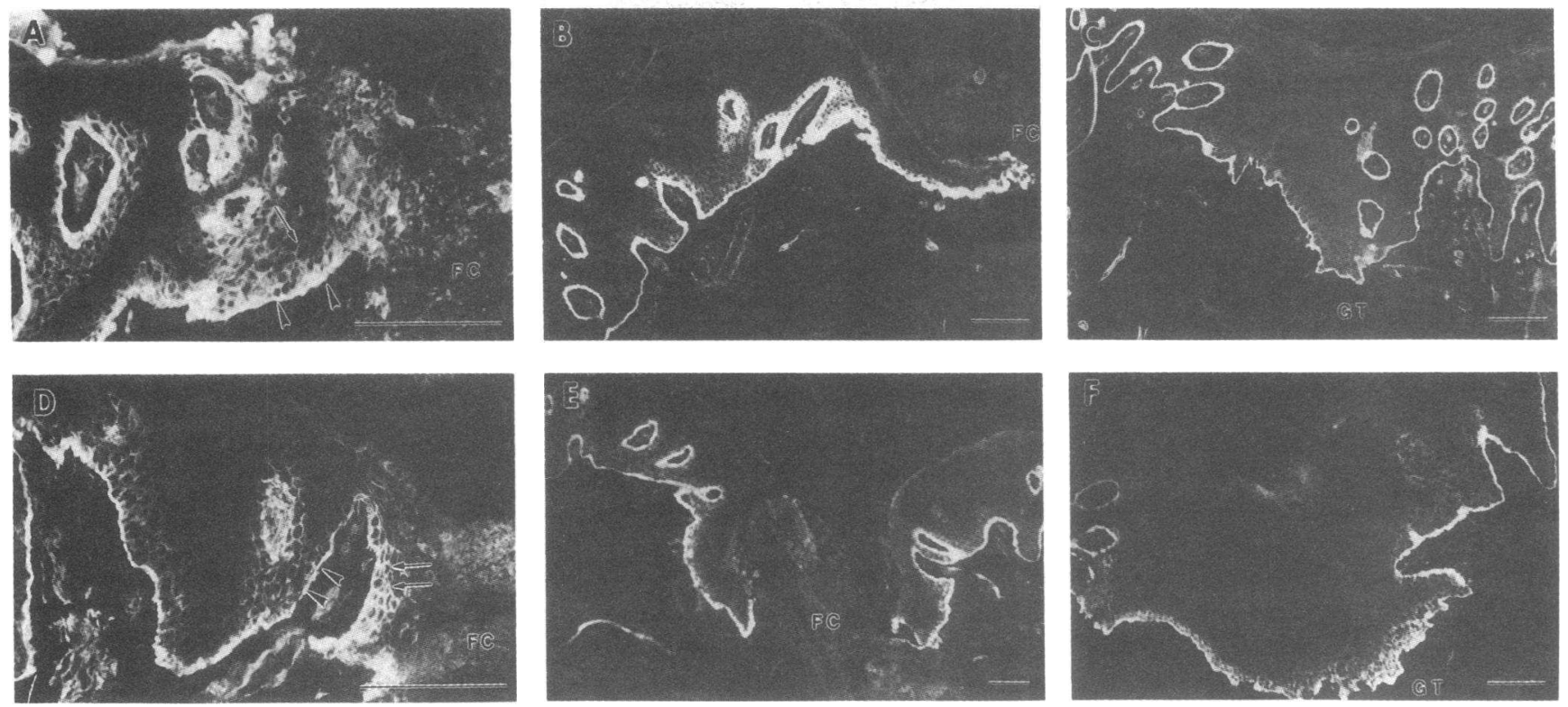

Figure 7. Immunolocalization of $\beta_{4}$-integrin $(A-C)$ and $\alpha_{6}$-integrin $(D-F)$ in 1-d-old $(A$ and $D), 3$-d-old $(B$ and $E)$, and 7-d-old $(C$ and $F)$ wounds. Staining surrounding cells in several keratinocyte layers at wound margin is marked by arrow $(A$ and $D)$. Bar, $50 \mu \mathrm{m}$.

or undetectable levels $(12,59)$. Keratinocytes migrating out from skin explants in culture start to express $\alpha_{5} \beta_{1}$ integrin (58). It is conceivable that some of the numerous cytokines present in wound fluid could up-regulate the expression of these integrins in the absence of the underlying basement membrane. Cytokines are known to regulate integrin expression in various cell lines $(60,61)$. In culture, both $\alpha_{\mathrm{v}}$ and $\alpha_{5}$ are expressed by keratinocytes $(13,14,17,18)$. The $\beta$-subunit associated with $\alpha_{v}$ was not $\beta_{3}$, but more likely $\beta 5$. Cultured keratinocytes express mainly $\beta 5$ associated $\alpha_{\mathrm{v}}$ subunits $(14,17)$. It is still, however, possible that wound keratinocytes express the $\alpha_{\mathrm{v}}$ subunit which associates with either $\beta_{1}$ or $\beta_{6}$ subunit forming fibronectin binding integrins (7).

The function of different integrins expressed by keratinocytes during wound healing is complex. Many of the members in the $\beta_{1}$-integrin subfamily change partially their specific lateralized distribution when keratinocytes migrate into the wound provisional matrix. Integrins were localized more at the cell surface projections facing the provisional matrix. One interesting hypothesis is that, in wounds, the cell-cell binding function of $\alpha_{2} \beta_{1}$ and $\alpha_{3} \beta_{1}$ is switched for binding extracellular ligands such as collagen, fibronectin, and epiligrin that are recognized by these receptors in vitro. Blocking the $\alpha_{2} \beta_{1}$ - and $\alpha_{5} \beta_{1}$-integrin function by antibodies inhibits keratinocyte migration on collagen and fibronectin, respectively (62). The role of $\alpha_{5} \beta_{1}$ is probably in fibronectin binding in keratinocytes since this is the only known ligand for this receptor (see reference 7). The $\alpha_{v} \beta_{5}$ is a vitronectin receptor (14). In some cases, $\alpha_{\mathrm{v}}$-integrins could serve as receptors for collagen if RGD containing peptides are present (63). This kind of peptides could rise from fibronectin during wound healing. They could regulate, not only the function of $\alpha \mathrm{v}$ integrins but also the expression of collagenase and stromelysin (34).

In mucosal wounds, $\alpha_{6} \beta_{4}$-integrin was present in the migrating keratinocytes. The $\alpha_{6} \beta_{4}$-integrin localizes in hemidesmosomes $(20-23)$ but it is not restricted to that location. It was recently shown that in an in vitro model of wound healing, $\alpha_{6} \beta_{4}$ appears along the entire cell surface of migrating keratinocytes in which the hemidesmosomes are absent (21). Epiligrin serves as a good candidate for a ligand for $\alpha_{6} \beta_{4}$ in migrating keratinocytes. Hemidesomosomes could then form at the sites where anchoring filaments and anchoring fibers are formed (64-66). The $\alpha_{6} \beta_{4}$ was often seen in several cell layers in the wound epithelium and not restricted to the basal surface of keratinocytes. During development of stratifying epithelia, $\alpha 6 \beta 4$ expression is not restricted to the basal surface of basal cells but found uniformly around basal cells (59). The ligand for $\alpha_{6} \beta_{4}$ in keratinocyte cell-cell contacts in these special cases remains to be shown.

Taken together, mucosal keratinocytes enlarge their integrin repertoire and distribution during wound healing. It is probably that these changes are regulated by both wound fluid cytokines and the extracellular ligands in the wound provisional matrix.

\section{Acknowledgments}

Ms. Marja Uola is gratefully acknowledged for her excellent technical help in stainings, and Ms. Eeva Eloranta for her expertice in preparing the figures. We also thank Dr. C. Damsky, Dr. K. Yamada, Dr. D. Woodley, Dr. L. Risteli, Dr. I. Virtanen, Dr. M. Hemler, Dr. A. Sonnenberg, Dr. V. Woods, Dr. A. Albino, and Dr. S. Kennel for providing antibodies for our studies.

\section{References}

1. Eckert, R. L. 1989. Structure, function, and differentiation of the keratinocyte. Physiol. Rev. 69:1316-1346.

2. Stenn, K. S., and R. Malhotra. 1992. Epithelialization. In Wound Healing Biochemical and Clinical Aspects. I. K. Cohe, R. F. Diegelmann, and W. J. Lindblad, editors. W. B. Saunders Co., Philadelphia. 115-127.

3. Humphries, M. J. 1991. Wound healing. In Receptors for Extracellular Matrix. J. A. McDonald and R. P. Mecham, editors. Academic Press, Inc., San Diego. 220-253.

4. Grinnell, F. 1992. Cell adhesion. In Wound Healing. Biochemical and Clinical Aspects. I. K. Cohe, R. F. Diegelmann, and W. J. Lindblad, editors. W. B. Saunders Co., Philadelphia. 209-222. 
5. Larjava, H. 1990. Expression of $\beta 1$ integrins in normal human keratinocytes. Am. J. Med. Sci. 301:63-68.

6. Albelda, S. M., and C. A. Buck. 1990. Integrins and other cell adhesion molecules. FASEB J. 4:2868-2880.

7. Hynes, R. O. 1992. Integrins: versality, modulation, and signaling in cell adhesion. Cell. 69:11-25.

8. Ruoslahti, E. 1991. Integrins. J. Clin. Invest. 87:1-5.

9. De Luca, M., R. N. Tamura, S. Kajiji, S. Bondanza, P. Rosino, R. Cancedda, P. C. Marchisio, and V. Quaranta. 1990. Polarized integrin mediates human keratinocyte adhesion to basal lamina. Proc. Natl. Acad. Sci. USA. 87:68886892

10. Hertle, M. D., J. C. Adams, and F. M. Watt. 1991. Integrin expression during human epidermal development in vivo and in vitro. Development (Camb.). 112:193-206.

11. Konter, U., I. Kellner, E. Klein, R. Kaufmann, V. Mielke, and W. Sterry. 1989. Adhesion molecule mapping in normal human skin. Arch. Dermatol. Res. 281:454-462.

12. Peltonen, J., H. Larjava, S. Jaakkola, H. Gralnick, S. K. Akiyama, S. S. Yamada, K. M. Yamada, and J. Uitto. 1989. Localization of integrin receptors for fibronectin, collagen and laminin in human skin: variable expression in basal and squamous cell carcinomas. J. Clin. Invest. 84:1916-1923.

13. Adams, J. C., and F. M. Watt. 1990. Changes in keratinocyte adhesion during terminal differentiation: reduction in fibronectin binding precedes $\alpha_{5} \beta_{1}$ integrin loss from the cell surface. Cell. 63:425-435.

14. Adams, J. C., and F. M. Watt. 1991. Expression of $\beta 1, \beta 3, \beta 4$, and $\beta 5$ integrins by human epidermal keratinocytes and non-differentiating keratinocytes. J. Cell Biol. 115:829-841.

15. Carter, W. G., E. A. Wayner, T. S. Bouchard, and P. Kaur. 1990. The role of integrins $\alpha 2 \beta 1$ and $\alpha 3 \beta 1$ in cell-cell and cell-substrate adhesion of human epidermal cells. J. Cell Biol. 110:1387-1404.

16. Hotchin, N. A., and F. M. Watt. 1992. Transcriptional and posttranslational regulation of $\beta_{1}$ integrin expression during keratinocyte terminal differentiation. J. Biol. Chem. 267:14852-14858.

17. Marchisio, P. C., S. Bondanza, O. Cremona, R. Cancedda, and M. De Luca. 1991. Polarized expression of integrin receptors $(\alpha 6 \beta 4, \alpha 2 \beta 1, \alpha 3 \beta 1$, and $\alpha \mathrm{V} \beta 5$ ) and their relationship with the cytoskeleton and basement membrane matrix in cultured human keratinocytes. J. Cell Biol. 112:761-773.

18. Carter, W. G., E. A. Wayner, T. S. Bouchard, and P. Kaur. 1990. The role of integrins $\alpha_{2} \beta_{1}$ and $\alpha_{3} \beta_{1}$ in cell-cell and cell-substrate adhesion of human epidermal cells. J. Cell Biol. 110:1387-1404.

19. Carter, W. G., P. Kaur, S. G. Gil, P. J. Gahr, and E. A. Wayner. 1990 Distinct functions for integrins $\alpha 3 \beta 1$ in focal adhesions and $\alpha 6 \beta 4$ bullous pemphigoid antigen in a new stable anchoring contact (SAC) of keratinocytes: relation to hemidesmosomes. J. Cell Biol. 111:3141-3154.

20. Jones, J. C. R., M. A. Kurpakus, H. M. Cooper, and V. Quaranta. 1991. A function for the integrin $\alpha_{6} \beta_{4}$ in the hemidesmosome. Cell Regul. 2:427-438.

21. Kurpakus, M. A., V. Quaranta, and J. C. R. Jones. 1991. Surface relocation of alpha beta $_{4}$ integrins and assembly of hemidesmosomes in an in vitro model of wound healing. J. Cell Biol. 115:1737-1750.

22. Sonnenberg, A., J. Calafat, H. Janssen, H. Daams, L. M. H. van der Raaij-Helmer, R. Falcioni, S. J. Kennel, J. D. Aplin, J. Baker, M. Loizidou, et al. 1991. Integrin $\alpha 6 / \beta 4$ complex is located in hemidesmosomes, suggesting a major role in epidermal cell-basement membrane adhesion. J. Cell Biol. 113:907-917.

23. Stepp, M. A., S. Spurr-Michaud, A. Tisdale, J. Elwell, and I. K. Gipson. 1990. $\alpha 6 \beta 4$ integrin herodimer is a component of hemidesmosomes. Proc. Natl. Acad. Sci. USA. 87:8970-8974.

24. Carter, W. G., M. C. Ryan, and P. J. Gahr. 1991. Epiligrin, a new cell adhesion ligand for integrin $\alpha 3 \beta 1$ in epithelial basement membranes. Cell. 65:599-610.

25. Rousselle, P., G. P. Lunstrum, D. R. Keene, and R. E. Burgeson. 1991. Kalinin: an epithelium-specific basement membrane adhesion molecule that is a component of anchoring filaments. J. Cell Biol. 114:567-576.

26. Puchtler, H., F. Sweat, and N. O. Doss. 1963. A one-hour phosphotungstic acid-hematoxylin stain. Am. J. Clin. Pathol. 40:334.

27. Larjava, H., J. Peltonen, S. K. Akiyama, S. S. Yamada, H. R. Gralnick, J. Uitto, and K. M. Yamada. 1990. Novel function for $\beta 1$ integrins in keratinocyte cell-cell interactions. J. Cell Biol. 110:803-815.

28. Roberts, C. J., T. M. Birkenmeier, J. J. McQuillan, S. K. Akiyama, S. S. Yamada, W. Chen, K. M. Yamada, and J. A. McDonald. 1988. Transforming growth factor $\beta$ stimulates the expression of fibronectin and of both subunits of the human fibronectin receptor by cultured human lung fibroblasts. J. Biol. Chem. 263:4586-4592.

29. Ylänne, J., M. Hormia, M. Järvinen, T. Vartio, and I. Virtanen. 1988. Platelet glycoprotein IIa/IIIa complex in cultured cells. Localization in focal adhesion sites in spreading HEL cells. Blood. 72:1478-1486.

30. Kennel, S. J., L. J. Foote, R. Falcioni, A. Sonnenberg, C. D. Stringer, C. Crouse, and M. E. Hemler. 1989. Analysis of the tumor-associated antigen TSP180. J. Biol. Chem. 264:15515-15521.

31. Hemler, M. E., F. Sanchez-Madrid, T. J. Flotte, A. M. Krensky, S. J. Burakoff, A. K. Bhan, T. A. Springer, and J. L. Strominger. 1984. Glycoproteins of 210,000 and $130,000 \mathrm{MW}$ on activated T cells: cell distribution and antigenic relation to components on resting cells and T cell lines. J. Immunol. 132:30113018.

32. Piscel, K. D., M. E. Hemler, C. Huang, H. G. Bluestein, and V. L. Woods 1987. Use of the monoclonal antibody $12 \mathrm{~F} 1$ to characterize the differentiation antigen VLA-2. J. Immunol. 138:226-233.

33. Kantor, R. R. S., M. J. Mattes, K. O. Lloyd, L. J. Old, and A. P. Albino. 1987. Biochemical analysis of two cell surface glycoprotein complexes, very common antigen 1 and very common antigen 2. J. Biol. Chem. 262:15158-15165.

34. Werb, Z., P. M. Tremble, O. Behrendtsen, E. Crowley, and C. H. Damsky. 1989. Signal transduction through the fibronectin receptor induces collagenase and stromelysin gene expression. J. Cell Biol. 109:877-889.

35. Sonnenberg, A., F. Hogervorst, A. Osterop, and F. E. M. Veltman. 1988. Identification and characterization of a novel antigen complex on mouse mammary tumor cells using a monoclonal antibody against glycoprotein Ic. J. Biol. Chem. 263:14030-14038.

36. Risteli, L., and R. Timpl. 1981. Isolation and characterization of pepsin fragments of laminin from human placental and renal basement membranes. Biochem. J. 193:749-755.

37. Verrando, P., B. L. Hsi, C.-J. Yeh, A. Pisani, N. Serieys, and J.-P. Ortonne 1987. Monoclonal antibody GB3, a new probe for the study of human basement membranes and hemidesmosomes. Exp. Cell Res. 170:116-128.

38. Larjava, H., C. Zhou, I. Larjava, and F. Rahemtulla. 1992. Immunolocalization of $\beta 1$ integrins in human gingival epithelium and cultured keratinocytes. Scand. J. Dent. Res. 100:266-273.

39. Stenn, K. S., and L. Depalma. 1988. Re-epithelialization. In The Molecular and Cellular Biology of Wound Repair. R. A. F. Clark and P. M. Henson editors. Plenum Press, New York. 321-335.

40. Clark, R. A. F., J. M. Lanigan, P. DellaPelle, E. Manseau, H. F. Dvorak, and R. B. Colvin. 1982. Fibronectin and fibrin provide a provisional matrix for epidermal cell migration during wound reepithelialization. J. Invest. Dermatol. 79:264-269.

41. Olerud, J. E., A. M. Gown, J. Bickenbach, B. Dale, and G. F. Odland 1988. An assessment of human epidermal repair in elderly normal subjects using immunohistochemical methods. J. Invest. Dermatol. 90:845-850.

42. Parente, M. G., L. C. Chung, J. Ryynänen, D. T. Woodley, K. C. Wynn, E. A. Bauer, M.-G. Mattei, M.-L. Chu, and J. Uitto. 1991. Human type VI collagen cDNA cloning and chromosomal mapping of the gene. Proc. Natl. Acad. Sci. USA. 88:6931-6935.

43. Sakai, L. Y., D. R. Keene, N. P. Morris, and R. E. Burgeson. 1986. Type VII collagen is a major structural component of anchoring fibrils. J. Cell Biol. 103:1577-1586.

44. Burgeson, R. E., G. P. Lunstrum, B. Rokosova, C. S. Rimberg, L. M. Rosenbaum, and D. R. Keene. 1990. The structure and function of type VII collagen. Ann. NY Acad. Sci. 580:32-43.

45. Woodley, D. T., P. M. Bachmann, and E. J. O'Keefe. 1988. Laminin inhibits human keratinocyte migration. J. Cell Physiol. 136:140-146.

46. Colvin, R. B. 1989. Fibronectin in wound healing. In Fibronectin. D. F Moshen, editor. Academic Press, Inc., San Diego. 213-254.

47. McDonald, J. A. 1988. Fibronectin: a primitive matrix. In The Molecular and Cellular Biology of Wound Repair. 405-435. R. A. F. Clark and P. M. Henson, editors. Plenum Press, New York

48. French-Constant, C., L. Van De Water, H. F. Dvorak, and R. O. Hynes. 1989. Reappearance of an embryonic pattern of fibronectin splicing during wound healing in the adult rat. J. Cell Biol. 109:903-914.

49. Clark, R. A. F., J. M. Folvord, and R. L. Wertz. 1985. Fibronectin, as well as other extracellular matrix proteins, mediate human keratinocyte adherence. $J$. Invest. Dermatol. 84:378-383.

50. Nickoloff, B. J., R. S. Mitra, B. L. Riser, V. M. Dixit, and J. Varani. 1988 Modulation of keratinocyte motility: correlation with production of extracellular matrix molecules in response to growth promoting and antiproliferative factors. Am. J. Pathol. 132:543-551.

51. O'Keefe, E. J., R. E. Payne, Jr., and D. T. Woodley. 1985. Spreading and enhanced motility of human keratinocytes on fibronectin. J. Invest. Dermatol 85:125-130.

52. Woodley, D. T., P. M. Bachmann, and E. J. O'Keefe. 1991. The role of matrix components in human keratinocyte reepithelialization. In Clinical and Experimental Approaches to Dermal and Epidermal Repair: Normal and Chronic Wounds. Wiley-Liss, Inc., New York. 129-140.

53. Engvall, E., D. Earwicker, T. Haaparanta, E. Ruoslahti, and J. R. Sanes 1990. Distribution and isolation of four laminin variants: tissue restricted distribution of heterotrimers assembled from five different subunits. Cell Regul. 1:731-740.

54. Marinkovich, M. P., G. P. Lunstrum, D. R. Keene, and R. E. Burgeson 1992. The dermal-epidermal junction of human skin contains a novel laminin variant. J. Cell Biol. 119:695-703.

55. Burgeson, R. E. 1993. Dermal-epidermal adhesion in skin: an example of a novel attachment mechanism mediated by the basement membrane. In Cellular and Molecular Aspects of Basement Membranes. R. Timpl and D. Rhorbach editors. Academic Press, Inc., San Diego 49-66. 
56. Clark, R. A. F. 1990. Fibronectin matrix deposition and fibronectin receptor expression in healing and normal skin. J. Invest. Dermatol. 96:1285-1345.

57. Guo, M., K.-I. Toda, and F. Grinnell. 1990. Activation of human keratinocyte migration on type I collagen and fibronectin. J. Cell Sci. 96:197-205.

58. Guo, M., L. T. Kim, S. K. Akiyama, H. R. Gralnick, K. M. Yamada, and F. Grinnell. 1991. Altered processing of integrin receptors during keratinocyte activation. Exp. Cell Res. 195:315-322.

59. Hertle, M. D., M.-D. Kubler, I. M. Leigh, and F. M. Watt. 1992. Aberrant integrin expression during epidermal wound healing and in psoriatic epidermis. J. Clin. Invest. 89:1892-1901.

60. Heino, J., and J. Massagué. 1989. Transforming growth factor $\beta$ switches the pattern of integrins expressed in MG-63 human osteosarcoma cells and causes a selective loss of cell adhesion to laminin. J. Biol. Chem. 264:21806-21811.

61. Santala, P., and J. Heino. 1991. Regulation of integrin-type cell adhesion receptors by cytokines. J. Biol. Chem. 266:23505-23509.

62. Kim, J. P., K. Zhang, R. H. Kramer, T. J. Schall, and D. T. Woodley.
1992. Integrin receptors and RGD sequences in human keratinocyte migration: unique anti-migratory function of $\alpha 3 \beta 1$ epiligrin receptor. J. Invest. Dermatol. 98:764-770.

63. Agrez, M. V., R. C. Bates, A. W. Boyd, and G. F. Burns. 1991. Arg-GlyAsp-containing peptides expose novel collagen receptors on fibroblasts: implications for wound healing. Cell Regul. 2:1035-1044.

64. Gipson, I. K., S. M. Grill, S. J. Spurr, and S. J. Brennan. 1983. Hemidesmosome formation in vitro. J. Cell Biol. 97:849-857.

65. Gipson, I. K., S. J. Spurr-Michaud, and A. S. Tisdale. 1988. Hemidesmosomes and anchoring fibril collagen appear synchronously during development and wound healing. Dev. Biol. 126:253-262.

66. Akimoto, Y., A. Obinata, H. Endo, and H. Hirano. 1992. Immunohistochemical study of basement membrane reconstruction by an epidermis-dermis recombination experiment using cultured chick embryonic skin: induction of tenascin. J. Histochem. Cytochem. 40:1129-1137. 